\title{
The Politics of the Two Qiblahs and the Emergence of an Alternative Islamic Monotheism
}

\author{
Eltigani Abdelgadir Hamid
}

\begin{abstract}
Absract
Changing the prayer direction from Makkah to Jerusalem and then back to Makkah was probably one of the first Muslim community's most contentious incidents. Due to its being highlighted in Q. 2:142-44, it has aroused an unending debate among Muslim exegetes, jurists, and western historians as to why the qiblah was changed. Was it based on a divine command or Muhammad's independent judgment, a move to dilute the Arabs' emotional attachment to the Ka'bah, or a move to win over Madinah's Jewish community? Might it have been a throwback to the Abrahamic heritage, envisaged by the Prophet as a base for a wider, monolithic Islamic nationalism? This article seeks to closely examine and clarify the "qiblah literature" in an attempt to reveal the Ka'bah's role not only as a geographical locale but also as a spiritual magnet, and to find out whether this incident represented a break or a continuation of an earlier strategy of socio-religious change.
\end{abstract}

\section{Introduction}

In its very basic Arabic meaning, qiblah designates the direction of the sacred mosque (al-Masjid al-Haram) toward which all Muslims must pray regardless of their geographic location. All jursits agree that Muslims used to perform shortened forms of prayers in Makkah. However, the exact prayer direction

\footnotetext{
Eltigani Abdelgadir Hamid is professor of politics and Islamic studies at Zayed University, UAE. He earned his Ph.D. in politics from the University of London (SOAS). Apart from numerous academic articles, he has authored four books, one of which,Ușül al-Fikr al-Siyāsi fi al-Qur' 'än al-Makkī, has been translated into English as The Qur'an and Politics. His publications deal with conceptual frameworks, state, and society. His current research focuses on social and political transformations in Muslim societies, political economy, and Qur'anic studies.
} 
remains unknown. Was it directed toward Makkah, or did they only start to face that city after they migrated to Madinah and explicitly instructed to do so (Q. 2:144)? If this was a post-hijra development, then did they pray toward Jerusalem while living in Makkah? Or was there no specific qiblah? These questions have become a center of prolonged discussion not merely because of an idle fascination with history, but because this change and its related issues had huge theological and political repercussions. In an attempt to settle this dispute, some Muslim commentators brought in the notion of "abrogation," whereas non-Muslim scholars posited the "Jewish factor." Both explanations, however, run into difficulties and are open to criticism, as will be shown below.

Although the primary focus is on the qiblah issue, this seven-section paper seeks to discuss the larger theological and political contexts of Islam's formative years. The first four sections analyze the exegetic, Hadith, and sirah material, in which the views of commentators and Hadith reports are thoroughly examined and evaluated. Section 5 focuses on the text itself in an attempt to bring in specific Makkan revelations that the commentators have mostly overlooked. Section 6 goes even deeper into the Makkan revelations and analyzes the Abrahamic and Mosaic heritages, together with some recent contributions to the topic. Section 7 wraps up the topic and presents my conclusions.

\section{The Qiblah Literature}

Looking into the Qur'an, which is the basic source of this debate, we come across thirty-nine occasions that mention the qiblah. Seven of them mention it explicitly, whereas the remaining thirty-two refer to al-Masjid al-Haram, al-Bayt, or the Ka'bah. Notwithstanding such repetition and recurrence, the Qur'an does not specify the geographical point toward which the Prophet prayed during the Makkan period, or whether he was following a specific Qur'anic command or conducting his own ijtihād (free reasoning). That being the case, we have to turn to the tafsirs (commentaries) as supplementary sources.

However, issues in this body of literature are not classified systematically according to subject; rather, they are scattered throughout the Qur'an's chapters. In order to impose a system that makes sense of these bits and pieces of information, it was perhaps Ibn Abbas and his disciples who began, during Islam's first century, to employ a methodology that enabled them to ask about various issues and formulate multiple answers that, consequently, shaped the entire tafsi $\bar{r}$ field. ${ }^{1}$ Working through this massive body of literature has enabled 
us to identify some relevant findings and positions that can broadly be divided into the following four versions, all of which are readily reported and freely circulated among the mufassirūn: the Jerusalem direction, the Makkan direction, the unspecified direction, and the united Makkah-Jerusalem direction. ${ }^{2}$

\title{
The Jerusalem Direction
}

This position, which is related to Ibn Abbas on the authority of Mu'awiyah ibn Abi Salih through Ali ibn Abi Talha, ${ }^{3}$ reads:

\begin{abstract}
When the Prophet migrated to Madinah and found that the majority of its population was Jewish, Allah directed him to pray toward Jerusalem. The Jews were then pleased. The Prophet continued to do so for some months, though his wish was (to pray) toward the qiblah of Ibrahim (Makkah). He used to look (during prayers) into the heavens. Then Allah revealed the verses: "We see the turning of thy face (for guidance) to the heavens. Now shall We turn thee to a qiblah that shall please thee. Turn then thy face in the direction of the Sacred Mosque." (Q. 2:144)
\end{abstract}

A similar account is also related to al-Barra ibn Azib (not to be confused with al-Barra ibn Ma'rur). However, his account differs on three crucial points: He did not say that the majority of Madinah's population was Jewish, that the Prophet's act was prompted by their presence, or that "Allah directed the Prophet toward Jerusalem."5

\section{The Makkan Direction}

Ibn Abbas also related this version on the authority of Mujahid. Ibn Jurayj, Sa'id ibn al-Musayyib, ${ }^{6}$ and al-Zamakhshari ${ }^{7}$ have all strongly supported it. In Ibn Jurayj's opinion:

The first prayer the Prophet performed was toward the Ka'bah, but later he was turned away (surifa) toward Jerusalem. Accordingly, the Ansar also prayed for about three years toward Jerusalem prior to the Prophet's immigration. Upon his arrival at Madinah, he continued to pray toward Jerusalem for sixteen months, after which Allah redirected him toward Makkah. ${ }^{8}$

\section{The Unspecified Direction}

This is the conclusion reached by Ibn Zayd (d. 128 AH), ${ }^{9}$ a client of Umar. He maintains that Muslims used to pray toward whatever direction they wanted, since they believed that all directions belong to Allah. Then Allah revealed: 
"To Allah belong the East and the West: whithersoever ye turn, there is Allah's Face" (Q. 2:115). The Prophet then said: "Those Jews have chosen one of Allah's Houses (referring to Jerusalem), so pray toward that direction." Hence the Prophet and the Muslims began to do so for some months (more than ten). Consequently, the Jews said: "He could not find the qiblah until we gave him guidance." The Prophet disliked what they said and raised his eyes (in prayer) to the heavens. Then Allah revealed: "We see the turning of thy face (for guidance) to the heavens: now shall We turn thee to a qiblah that shall please thee. Turn then thy face in the direction of the Sacred Mosque (Q. 2:144). ${ }^{10}$

\section{The United Makkan/Jerusalem Direction}

Ibn Abbas also related this account through the reports of al-A'mash and Mujahid: "While in Makkah his qiblah was toward Jerusalem. But he used to situate the Ka"bah between him and the Jerusalem Mosque" (känat qiblahtuh bi Makkah Bayt al-Maqdis, illā annahu kāna yaj'al al-Ka 'bah baynahu wa baynahu). ${ }^{11}$ In other words, he prayed toward the sacred mosque of Jerusalem while facing the Ka'bah. After migrating to Madinah, he continued to pray toward Jerusalem until he was redirected toward the Ka'bah.

\section{An Assessment}

At the heart of these four competing accounts is a disagreement about facts. There appear to be two opposite contentions: (1) those who support the "new start" thesis (i.e., the qiblah of Jerusalem was inaugurated only after the Prophet arrived in Madinah) and (2) the upholders of the "continuation" thesis, those who hold that this was not a new policy because the Prophet had been praying toward it while living in Makkah.

The "new start" hypothesis is related to al-Barra and Ibn Abbas, who were later followed by other commentators and scholars. Their major point can be construed in the following fashion: Upon his arrival at Madinah and in recognition of the Jewish influence therein, the Prophet decided to pray toward Jerusalem. There is, however, no agreement among the exponents of this view on whether that decision was based on a divine command (as stated in Ibn Abbas' version) or was a political initiative of the Prophet (as can be inferred from al-Barra's report). ${ }^{12}$ It is important to note here that neither of them mentioned anything about a Qur'anic verse being abrogated. But three of Ibn Abbas' disciples, namely, al-Hassan, 'Ikrimah, and Abu al-'Aliyah, asserted that this was what had happened to the qiblah verses. ${ }^{13}$ Accordingly, two issues were mixed up: appeasing the Jews and abrogating some verses. 
Confronted by the fact that no Qur'anic verses can be interpreted as instructing the Prophet to pray toward the Jerusalem mosque, some upholders of the abrogation thesis changed their position, saying that his sunnah was abrogated. ${ }^{14}$ Other mufassirūn and jurists who shared this view but were uncomfortable with a Qur'anic verse abrogating a sunnah cited "whithersoever ye turn, there is Allah's Face" (Q. 2:115) as the needed evidence. ${ }^{15}$ But upon close examination, this Madinan verse does not oblige the Prophet to pray toward Jerusalem, and hence it is pointless to assume that it was abrogated.

Lastly, the abrogation hypothesis was dealt a strong blow by some critics of Hadith who questioned the validity of Ibn Abi Talha's report on the basis of inqit $\bar{a}$ ' (disconnection) ${ }^{16}$ : He had not heard it directly from Ibn Abbas. But even if he had, it is considered mawqū ${ }^{17}$ (suspended) because Ibn Abbas had not heard it directly from the Prophet. Thus al-Bukhari and Muslim considered it a personal opinion and did not include it in their Șahīhs. Moreover, if this opinion is truly related to Ibn Abbas, it contradicts the united Makkan/Jerusalem direction, which is also related to him through Mujadid and al-A'mash.

The second account ${ }^{18}$ is plausible because it is reported, independently, that the Ansar were also praying toward Jerusalem, an act that must have been based on the Prophet's instruction or approval. If true, this report also invalidates the notion of wooing the city's Jews, for why should the Prophet face Jerusalem prior to his encounter with them? The only problem here is that it says nothing about the authority on which the Prophet based his shift or why he did so. It is claimed that he was redirected (șurifa) toward Jerusalem, but the exact verses (if there were any) that redirected him are not mentioned.

Relating the Makkan period to the Madinah period, the third account may present a sound argument. Ibn Zayd maintains that no specific qiblah direction was prescribed while the Muslims were in Makkah; that the choice was left to the Prophet; and that, accordingly, he decided to pray toward Jerusalem in line with what he saw as an "established prophetic tradition." Nevertheless, this account is silent on at least two points: When did he shift the direction to Jerusalem, and was the "established prophetic tradition" that of facing toward Makkah or Jerusalem?

The united Makkan/Jerusalem direction attempts to reconcile all of the clashing opinions. ${ }^{19}$ After his migration, the Prophet dropped the Makkan qiblah and "continued" to pray toward Jerusalem. Although no justification for doing so is given, it could be based on a very simple geographical fact: Praying toward Makkah and Jerusalem simultaneously could be done only if one was physically in Makkah. ${ }^{20}$ As for why he chose to face Jerusalem instead of Makkah, no conclusive answer can be given. A. J. Wensinck and other western 
scholars ${ }^{21}$ say, following one of the views related to Ibn Abbas, that he continued to pray toward Jerusalem to win the Jews' sympathy. Wensinck argues that once the Prophet arrived in Madinah, he turned more and more to the religion of Abraham and made it the basis of his monotheistic religion. In his view, the Prophet changed the prayer direction because he failed to win over the Jews. Thus, in a moment of disappointment he turned away from Jerusalem and began talking of the Ka'bah and the hajj as a Muslim rite. ${ }^{22}$

In his Muhammad: Prophet and Statesman, M. Watt provides a diametrically opposite perspective: "The change of qiblah," he says, "could be interpreted as a gesture to some of Madinah's anti-Jewish clans to win their support and show that Muhammad was committing himself to them." ${ }^{23}$ Curiously enough, a third explanation is provided by Abu Ishaq al-Zajjaj (d. 311 $\mathrm{AH})$, the grammarian mufassir who was the first one to emphasize the idea of the Ka'bah-centered Arab sentiment: The qiblah was initially diverted from Makkah to Jerusalem to test the Arab polytheists, who had become too attached to the Ka'bah (alifu al-Ka'bah). ${ }^{24} \mathrm{Al}$-Zamakhshari and Sayyid Qutb also agreed with this view. ${ }^{25}$ And yet all of them are problematic and open to criticism, as will be shown below.

\section{The Hadith Literature}

Checking the tafsir literature, based on various reports related to Ibn Abbas and his disciples, has shed some light on this issue. But since these reports are ridden with inconsistences and provide no satisfactory answers to many questions, it might be better to turn to the Hadith literature, namely, to alBukhari (d. $256 \mathrm{AH})$ and Muslim (d. $261 \mathrm{AH})$.

In his Sahịh and in keeping with his fiqh-based method of Hadith classification, al-Bukhari presents his qiblah-related material in various sections. In the chapter on tafsir , he dedicates six sections to the issue of the qiblah and its change. Under each section he brings a hadith, most of which are reported on the authority of al-Barra, Ibn Umar, Anas, and other Companions. ${ }^{26}$ None of the reports, however, come through Ibn Abbas. Remarkably, al-Bukhari never mentions any hadith that could throw some light on the prayer direction during the Makkan period. Commenting on "But Allah would never let your faith to waste" (Q. 2:143), he says: "'Your faith' means your prayer at the House (șalātukum 'ind al-Bayt)."

Unexpectedly short, this statement is also "problematic," as Ibn Hajar, the renowned commentator and editor of al-Bukhari's work, notices, for it does not directly address that particular question. Clarifying al-Bukhari's 
meaning, Ibn Hajar devised the following explanation: "As if he was alluding to the confirmed and valid opinion that the prayers at the House (Makkah's holy mosque) were directed toward Jerusalem. ${ }^{.27}$ But this is exactly what Ibn Abbas reported in his report, which al-Bukhari excluded from his Șahịh.

Muslim's (d. 261) Sahịh contains almost the same hadiths reported by alBukhari. But instead of confining himself to the fiqhi side, Muslim focused on the general subject of mosques, which led him to bring in some material on the Madinah mosque and link it to the Ka"bah-Jerusalem discourse. This approach resulted in what later came to be known as the "merits of Median" literature. He divided this material into, among other sections, the demolition of the Ka'bah, the permissibility of staying in Makkah, the merits of Madinah, and "that no riding camel should be saddled." 28 In none of these sections do we see anything related to the qiblah.

It seems rather surprising that neither al-Bukhari nor Muslim provided specific information on the qiblah, as we had expected. But seen from another perspective this could be important, for if they found no authentic hadith related to the Prophet on why the qiblah was changed, we could consider these contending views as nothing more than personal opinions and examine them on their own merits.

\section{The Sïrah Literature}

Not completely satisfied with what I found in the Hadith literature, I decided to check the sirah sources, the earliest one of which is that of Ibn Ishaq (d. 213 $\mathrm{AH})$, which has been reproduced by Ibn Hisham as Al-Sirah al-Nabawiyah. Sifting through this voluminous work, we encounter three cases that are closely related to the question of qiblah: the attack on Abdullah ibn Mas'ud, the violent reaction of Sa'd ibn Abi Waqqas, and the Makkan orientation of alBara' ibn Ma 'rur.

The attack on Ibn Mas' $u d$, being the earliest incident of confrontation, is intensively highlighted in the sirrah sources. It is reported on the authority of 'Irwa ibn al-Zubayr that his father said:

The first person (after the Prophet) who publicly recited the Qu'ran in Makkah was Abdullah ibn Mas'ud. The Companions met one day and said, "By God, the Quraysh have never heard this Qur'an recited publicly to them. Can any one of you do that?" Abdullah ibn Mas'ud said, "I will." The Companions said, "We fear that they (the Quraysh) will harm you. We need someone who has 'ashīrah (a strong clan) to protect him." Ibn Mas'ud said, "Let me go, and God will protect me." He left them and headed toward the Ka"bah 
until he reached al-Maqam in the early morning, where members of the Quraysh were sitting in their usual places. Standing up at the Maqam, Ibn Mas'ud began reciting "In the name of God, al-Rahmān, 'alam al-Qur'ān," raising his voice with that. When the Qurayshi leaders realized that he was reciting the same message that Muhammad was preaching, they were outraged and started slapping him. But he continued to recite. When he returned to his friends with an injured face, they said, "This is exactly what we feared." 29

The Prophet probably anticipated and feared this as well. It becomes clear, then, that public recitations of Qur'anic verses either inside or around the Sacred House were not tolerated. In fact, such activities might lead to fighting.

The second incident, Sa 'd ibn Abi Waqqas' violent reaction, is reported by Ibn Hisham.

Whenever they wanted to pray, the Companions would go along (Makkah's) mountain trails $\left(s h i^{`} \bar{a} b\right)$ to conceal their prayers from their fellow Makkans. One day, when Sa'd ibn Abi Waqqas and a small group of Companions were praying at one of these trails, a small group of (Makkan) polytheists appeared and began blaming and bothering them so much so that they were soon drawn into a fight. At that juncture, Sa'd ibn Abi Waqqas struck a polytheist with a dead camel's jaw (or leg) and injured him. That was the first blood to be shed in Islam. ${ }^{30}$

The obvious significance of this incident might help us answer why the Prophet choose to pray toward Jerusalem. According to this account, he did so to avoid such unnecessary confrontations and bloodshed. But such goals could not be achieved merely by diverting the prayer direction. Other drastic measures were certainly needed, and one of them turned out to be migration. This is most likely one of the reasons why he told some of his Companions to secretly migrate to Abyssinia, to "disperse all over the land and God will reunite you." (Tafarraqu fi al-ard fa inna Allāha sayajma 'ukum). ${ }^{31}$

A cursory reading of the sirah sources might give two wrong impressions: that these migrants were the weakest Muslim slaves who were exposed to torture (e.g., Bilal and Ammar) and that their numbers were negligible. In fact, about eighty-three free and formidable personalities, among them al-Zubayr ibn al-'Awwam, Abd al-Rahman ibn 'Awf, Ja'far ibn Abi Talib, 'Uthman ibn 'Affan, and 'Amr ibn Sa'id ibn al-'As accompanied the persecuted slaves. ${ }^{32}$ Had the Prophet allowed them to stay in Makkah, where they could have been humiliated or provoked, they surely would have retaliated in the same way as Sa'd ibn Abi Waqqas had. To avoid such incidents, the Prophet told them "disperse," thereby reemphasizing his non-confrontation policy. 
It has perhaps become clear that the Prophet first "refrained" from praying at the Makkan shrine and then instructed all of his followers to move to Madinah for a political reason: to avoid unnecessary fights with the Qurayshi leaders over the Ka 'bah. Had he chosen to remain, the nature of the struggle might have been obscured and he would have been seen as one who wants to rekindle old tribal feuds and jealousies. The entire issue would have been seen as a nationalistic struggle over the Ka'bah or a clannish struggle between the Banu Abd Shams and Banu Abd al-Muttalib for its ownership. In other words, Muhammad would have appeared as someone who fights to regain his grandfather's position. ${ }^{33}$

However, this calculated and temporary withdrawal must not be misunderstood as absolute and final. In the Prophet's initial belief, the Ka'bah was still the original qiblah and the Muslims would one day be able to face it in their prayers or assert their control over it. This view can be seen in the case of al-Barra ibn Ma'rur a senior Companion and distinguished Ansari leader.

Sometime before the hijra, al-Barra and a group of his people were travelling from Madinah to Makkah. When it was time to pray, he announced that he had decided to orient himself to the Ka'bah. The group refused to follow him on the grounds that the Prophet prayed toward al-Sham (i.e., Jerusalem) and that they could not disobey him. When they reached Makkah, al-Barra said to the Prophet: "I set out on this trip and decided not to leave this building (e.g., the Ka'bah) behind me. Thus I faced it during my prayers, whereas my companions did not. I feel bad about this. What do you say?" The Prophet replied: "You were facing a (true) qiblah. If only you had been patient" (la qad kunta 'alā qiblah, law sabarta 'alāyha). ${ }^{34}$

This incident, which no sirah or Hadith expert has ever disputed, provides further support for the united Makkan/Jerusalem thesis that Ibn Abbas reported. It shows that while the Prophet himself was praying toward Jerusalem, he was keeping an eye on Makkah and did not discourage people from facing it, provided that they took the necessary precautionary measures.

\section{The Qiblah in the Makkan Verses}

So far, most of our attention has been given to the works of Qur'an and Hadith commentators, despite the fact that the greater part of them focus almost exclusively on the so-called qiblah verse (i.e., Q. 2:144), which was revealed at Madinah. Once in that city, the Prophet and his followers were explicitly directed to turn once and for all toward Makkah. This caused the commentators to view this event as a complete abandonment of Jerusalem or as a new discovery of the Makkan qiblah. 
Other pre-Madinah verses, among them "[He is] Lord of the East and the West" (Q. 73:9) and "Let them worship the Lord of this House" (Q. 106:3), which contain frequent references to the Holy Houses of joint worship indicate an earlier intensive Qur'anic concern with the Makkan shrine, tend to be overlooked. For example, in Q. 95:1-3, the Prophet was specifically told to consider the "link" among the land of the Fig and Olive (Jerusalem), Mount Sinai, and the City of Security (Makkah, Q. 95), with its much-frequented House (al-Bayt al-Ma'mūr, Q. 52:4). Along the same lines, the Prophet was reminded, right from the beginning of his mission, that the same fundamental truth revealed to him had also been expressed in the "earlier scriptures" (alșuhuf al-ūlā) of Abraham and Moses (Q. 87:18-19; 20:133).

It is worth recalling here that before Islam's advent, the Quraysh had asked Muhammad to arbitrate ${ }^{35}$ their struggle over who would control al-Bayt alHaram. When he went public with his mission and began reciting Qur'anic verses that slightly criticized the Quraysh's misuse of the Ka'bah, a new conflict developed between him and its leaders, especially with his immediate cousins, the Banu 'Abd Shams, who now saw him as a competitor instead of as the arbitrator he used to be.

The earliest signs of the Qur'anic criticism and disapproval of this "misuse" is "My signs used to be rehearsed to you, but ye used to turn back on your heels in arrogance: talking nonsense (around the Ka'bah) about the Qur'an, like one telling fables at night" (Q. 23:66-67). The basic meaning here centers on the pronoun bihi, which refers to the Sacred Mosque or the Qur'an that was recited in the public space around it. ${ }^{36}$ The implicit objection runs like this: "You (Quraysh's leaders) claim to be the Ka'bah's custodians and protectors, yet you misuse it (e.g., turn it at night into a place of sins and avarice) by leaving out the Prophet and the Qur'an." Other signs of criticism and disapproval are: "And the places of worship are for Allah (alone): so invoke no one along with Allah" (Q. 72:18) and "Let them worship the Lord of this House, who provides them with food against hunger, and with security against the fear of danger" (Q. 106:3).

Given this explicit trend, one might think that the Prophet's next step would be to seize the Ka'bah. But at the time this was neither possible nor useful. Instead, two pieces of valuable counsel were conveyed to him. The first one was: Be patient and rest assured that God is a transcendental being. The Ka'bah is His House only in a metaphorical sense, because God is not space-limited. To make this point clear, a new Qur'anic concept, namely, "Lord of the East and the West" was introduced in Q. 73:9 and repeated on other occasions (e.g., Q. 28:26, 9:73, 40:70, and 17:55). The second one was: Follow a policy of partial and temporary withdrawal from the Ka'bah in order 
to avoid any confrontations for which the Muslims were not ready. This is conveyed in the next verse: "And have patience with what they say, and leave them with noble dignity, and leave Me alone with those in possession of good things of life" (Q. 73:10-11). The Arabic ihjur (in the imperative) literally means to dissociate, keep away, emigrate, avoid, or part company. It is possible that the Prophet translated wa ahjurhum as avoiding the Qurayshi leaders. Hence he began to focus on reciting the Qur'an and performing the voluntary night prayers, which do not require a qiblah or a mosque.

This prophetic way of translating divine commands into actions and policies is worth analyzing, for it shows that he based his decisions on three interrelated components: the Qur'anic text, his own interpretation of that text, and his assessment of the real-world situation. It is rather surprising that some exegetes and Hadith experts have not noted this dynamic internal relationship between the Prophet and the Qur'an, or the external relationship between him and the real world. Whenever the Qur'an introduced a concept, laid down a general rule, or passed a value judgment, the Prophet would try to adapt it to the real world. If something went extremely wrong in this process, new verses would be revealed to rectify the situation, a process that in some Qur'anic passages is referred to as "abrogation." ${ }^{37}$

In light of the Prophet's threefold function, namely, as a receiver, interpreter, and actor, we can understand most of his political steps, among them his secret trip to al-Ta'if, sending some of his Companions to Abyssinia, secret contacts and negotiations with tribal leaders, and undisclosed final emigration to Madinah. Similarly, we should assume that his "withdrawal" from Makkah was a temporary policy based on his own interpretation of "And have patience with what they say, and leave them with noble dignity" (Q. 73:10) as well as on his understanding of the balance of power between his tiny group and the formidable Qurayshi leadership.

It must be noted, however, that this withdrawal was accompanied by a strong expectation of a victorious "return" (based on an interpretation of "Their purpose was to scare thee off the land, in order to expel thee; but in that case they would not have stayed therein after thee" [Q. 17:76-77 and other verses] and a return to a new Makkah that would be stripped of its clannish cloak and situated within a wider and deeper monotheistic tradition, as will be shown below. Surprisingly al-Zamakhshari, the Persian-born commentator, was the only tafsir expert to grasp this idea of temporary withdrawal. The Prophet, he contends, was originally inclined toward the Ka'bah but faced Jerusalem both temporarily and for a purpose. ${ }^{38}$

In concluding this section, one point stands out: The Makkan sürahs related to the qiblah and the prayers overlap with the early Madinan revelations, 
particularly as regards Qur'an 2. If one looks carefully into the above-mentioned Makkan verses and tries to relate them to the immediate textual context of the oft-quoted Madinah verse "And We appointed the qiblah to which thou was used, only to test those who followed the messenger from those who would turn on their heels (Q. 2:143), it would appear that this latter verse is an extension of the Makkan verses. In fact, the passages that come both before and after it are rejoinders that recapitulate and expand upon previous discussions and comments spread over the Makkan sürahs, ${ }^{39}$ as will be shown below.

\section{The Abrahamic and Mosaic Heritages}

The Makkan verses referred to above do not exhaust all of the information on the Ka'bah. Several of the other longer Makkan sürahs provide more information not only on the Makkan qiblah, but also on Abraham, the monotheistic father-Prophet who founded it, and on the spiritual and historical contexts within which the concept of qiblah acquired its importance and significance. Aspects of his story appear in thirty-two Makkan passages: idol-worshippers (Q. 21:51-73; 26:69-77), his frank conversation with his father and the latter's furious response (Q. 19:41-47), his hijra and sojourns (Q. 19:49), the good tidings he and his wife received (Q. 11:69-76), and his efforts to purify the Ka'bah (Q. 22:26).

Our purpose here, however, is to explore Q. 14 and Q. 17, both of which are late Makkan revelations of particular relevance to our inquiry: They provide a unifying narrative that opens up the stories of Abraham, Moses, and Muhammad into each other, as well as associate Makkah's Sacred Mosque with its Jerusalem counterpart. Moreover, all of them are situated within the common trans-tribal Abrahamic monotheistic tradition.

When reading through Q. 14, one immediately notices that the opening verses present a concise summary of the Prophet's mission: to "bring forth all humanity, by their Sustainer's leave, out of the depths of darkness into light." With some variations in its scope of jurisdiction, ${ }^{40}$ this is the same mission entrusted to all of Muhammad's predecessors. Ironically, prophets appointed to fulfill these tasks are themselves forced into the darkness of exile, as we are told in the middle of the chapter.

The chapter's centerpiece, from which its title is derived, is Abraham's heartfelt prayer.

And [remember the time] when Abraham spoke [thus]: "O my Sustainer! Make this land [Makkah] secure, and preserve me and my children from ever worshipping idols, for verily, O my Sustainer, these [false objects of worship] have led many people astray! Hence, [only] he who follows me 
[in this my faith] is truly of me, and as for him who disobeys me, Thou art, verily, much-forgiving, a dispenser of grace! O our Sustainer! Behold, I have settled some of my offspring in a valley in which there is no arable land, close to Thy sanctified temple, so that, $\mathrm{O}$ our Sustainer, they might devote themselves to prayer. (Q. 14:35-41)

In this illuminating prayer, and after referring explicitly to both branches of his family, namely, the sons of Ismail (the Arabs) and of Isaac (the Jews), Abraham prays for all of the believers. His prayer is recalled in this place to illustrate, in one commentator's view, that the new revelation (the Qur'an) bears out the same universal revelation of prayer, charity, and love of Allah and humanity, wherein the universality of Islam will bless all believers from all nations. ${ }^{41}$ A corollary of this view may be the acknowledgment of the "ancestral" heritage shared by Jews, Christians, and Muslims. ${ }^{42}$

Apart from this prayer, the chapter stresses the idea of the forced "repulsion from the land" that most prophets, we are told, had encountered, starting with Abraham, the émigré prophet par excellence, to Moses, who led his people in a phenomenal exodus. Several verses describe the provocative threats issued by haughty unbelieving leaders to their seemingly powerless prophets, followed by a solemn divine promise: "And the unbelievers said to their messengers: 'We shall most certainly expel you from our land, unless you return forthwith to our religion." This threat is immediately followed by a comforting divine promise: "Most certainly shall We destroy these evil-doers, and most certainly shall We cause you to dwell on Earth long after they have passed away" (Q. 14:13-14).

The optimistic connotation here is unmistakable, for these verses refer to the "cyclical" feature of human history. Although painful and frustrating, such forced expulsions may pave the way for the prophets' inevitable return and triumph, thereby leading to the unbelievers' collapse and removal from the land, provided that certain prerequisites are met. The lessons to be drawn from this chapter are twofold: (1) The Makkan leaders learned that they might expel the Prophet and his followers, but that they will find themselves on the losing side because Allah will protect the Muslims and (2) the Muslims learned that even though they might be persecuted and expelled, one day they will return in triumph and inherit the land.

The second chapter is Q. 17, which is known both as The Night Journey and, interestingly, the Children of Israel. Its dominant themes are clearly expressed in the opening verses, which reveal the Prophet's unobserved night journey from Makkah's Sacred Mosque (al-Masjid al-Haram) to its Jerusalem counterpart: the Farthest Mosque (al-Masjid al-Aqsa). This account is imme- 
diately followed by an explicit reference to Moses and the Book that was given to him as "a guide to the children of Israel" (Q. 17:2). The chapter then describes some turning points in the Israelites' history that took place around the Farthest Mosque.

The Qur'an declares that the Prophet's night journey was designed to "expose him to some of Our Signs" (li nurīyahu min ayātinā; Q. 17:1), which probably refers to the same "cyclical" features of history exposed in Q. 14, namely, incidents and experiences in which the Jews, Christians, Romans (i.e., Byzantines), and Persians had been involved. The concept of "expulsion from the land" is reemphasized here as well, but with one difference: It is formulated as God's direct proclamation to the Prophet: "Their purpose was to scare thee off the land, in order to expel thee; but in that case they would not have stayed therein after thee except for a little while. [This was Our] way with the messengers We sent before thee: thou wilt find no change in Our ways" (Q. 17:76-77).

Reflecting on these two chapters (Q. 14 and Q. 17), one notices the emergence of the notion of "God's way" (sunnat Allahh), a reference to a law-like regularity that the Prophet could not miss. According to this notion, the history of earlier prophets may be understood in terms of an opposition between prophets and their poor and oppressed followers ${ }^{43}$ and the arrogant disbelieving holders of power. Anticipating a disruption of their status quo, the latter group hastens to both outlaw and "expel" the former group, who accept their lot patiently and enter their phase of "punitive exile." But stimulated by the prophetic vision and spiritual impetus, they may acquire solidarity and strength - qualities that, in Qur'anic terminology, develop through the hardships and sufferings experienced during their "expulsion." Although usually outnumbered by the unbelievers, the prophets and their followers not only "return" from their exile, but also triumph over and replace their powerful opponents in the land. ${ }^{44}$

This concept of "withdrawal and return" deserves more attention, because it has recently acquired a powerful explanatory potential. In non-Qur'anic sources, it is of course traceable to Plato's metaphor of the cave..$^{45} \mathrm{Ibn}$ Khaldun (d. 1406), ${ }^{46}$ the Muslim philosopher of history, resuscitated it in the Islamic tradition, after which it was much later appropriated and popularized by the world historian Arnold Toynbee (d. 1975) in his Study of History. Expanding this idea into a systematic explanatory framework, Toynbee tried to make it congruent with Muhammad's exile from and return to Makkah. ${ }^{47}$ What both scholars noticed can be construed to mean, among other things, that the hijra and all that happened thereafter, including the change of qiblah and the revival of the Abrahamic heritage, was part of a pre-planned course of action. ${ }^{48} \mathrm{Re}-$ lating these two chapters to one another and to the Prophet's precarious polit- 
ical situation during his last years in Makkah, it would not be improbable to assume that he might have entertained the idea of his impending hijra and thus was looking for potential allies who could somehow help him encircle the Quraysh. In other words, how could he recite whole passages about hijra and not notice his own probable hijra and the consequent divine promise?

Now that we have been introduced to Abraham, the founder of the Ka'bah, promulgator of monotheism, and venerated ancestor of both the Jews and the Arabs, as well as to the former's trials and troubles around Jerusalem, it is time for us to work out the possible implications for the Prophet and his emerging community.

\section{Islamic Monotheism}

The process of recalling the Abrahamic heritage must have conveyed a clear message to the Prophet. The past is recalled, as John Dewy says, "not because of itself but because of what it adds to the present." ${ }^{49}$ Immersed in the ancient history of prophets relayed by Makkan revelations and facing an imminent threat from his enemies, it seems most likely that his attention would be inclined toward a two-track policy: (1) the immediate "political" realities and considerations, namely, forging a broad tribal coalition that might include the Jewish community against the Quraysh forces and (2) reviving the deeper "spiritual" connections between Makkah and Jerusalem as the holy centers of an earlier monotheistic tradition. This would allow Muhammad to present himself as a proponent of that tradition, along with Abraham and Moses.

A good number of verses made this "monotheistic tradition" abundantly clear to the Prophet. During his miraculous Night Journey, this point became even clearer. In the words of Muhammad Asad, the purpose of this event was "to show that Islam is not a new doctrine but a continuation of the same divine message which was preached by the prophets of old, who had Jerusalem as their spiritual home." ${ }^{, 50}$ Indeed, some Makkan verses (e.g., Q. 6:90) explicitly directed the Prophet "to follow the guidance" received by the earlier prophets; other verses informed him that the Qur'an is part of "the Mother of the Book" (umm al-kitāb) from which all other scriptures had been revealed (Q. 13:39). Therefore, it was only natural for him to situate himself and his religion within the monotheistic tradition of Abraham and Moses. Moreover, it was also only natural for him to redefine his followers' identity in such a way that personal piety, national identity, and the transnational Abrahamic spiritual heritage would be united and linked to the one supreme God. And as both Abraham and Moses constitute part and parcel of this spiritual continuum, so do the Ka'bah and Jerusalem. 
From this standpoint, the fundamental "contradiction" is not between the Prophet and the true and sincere followers of Abraham and Moses (the "People of the Book," some of whom were suffering Roman [i.e., Byzantine] and Persian persecution), but between him and the idol worshippers who had hijacked the Makkan shrine and exploited it for their own material interests, thereby blocking the spread of his message among the Arab tribes. Based on this conception, the Prophet was waiting for the balance of power to turn in his favor. As soon as this happened, he began to terminate the hijra phase and embark upon a policy of return.

But then a serious credibility problem propped up: How could he proceed without giving a wrong and confusing impression to the Jews, the Qurayshi polytheists, and his followers? Facing such a multidimensional problem, the Prophet felt that his own ijtihād (personal judgment) was not enough and so he raised his eyes to heaven looking for $i d h n$, a higher supportive permission. ${ }^{51}$ It was against this background of suspense and tension that Q. 2:244 was revealed: "We see the turning of thy face (for guidance) to the heavens: now shall We turn thee to a qiblah that shall please thee. Turn then thy face in the direction of the Sacred Mosque."

This verse, enjoining an immediate change of qiblah, can be understood as securing the Qur'anic approval for which the Prophet had been waiting. But more importantly, it also widened the concept of qiblah in such a way that it revived the Makkan mosque and preserved the option of praying to any other direction (including Jerusalem) during the optional prayers. ${ }^{52}$ A new, wider concept of "Islam" itself was also reemphasized, according to which Islam has remained the religion of all prophets, from Abraham and onward to Jacob, Moses, Jesus, and Muhammad. In line with both of these newly expanded concepts, the Prophet widened the concept of mosque. In his Sunnan, Ibn Majah, one of the six imams of Hadith, reports on the authority of al-A'mash that Abu Dharrr once asked the Prophet about the world's first mosque. The Prophet told him that it was al-Masjid al-Haram. "What was the second?" Abu Dharr asked. The Prophet told him it was al-Masjid al-Aqsa and then added, "and then (in addition to these two mosques) all of Earth has been made a mușalla (mosque) for you, so pray wherever the prayer time arrives. ${ }^{.53}$

A corollary of this concept meant that the Prophet was not expected to focus on the disjunctive concept of the "centrality" of either Jerusalem or Makkah, but to develop a harmonizing synthesis that would place both cities, and later on Madinah, on the same level as genuine spiritual centers. "No riding camel," he says, "should be saddled (i.e., start out a journey) except to (these) three mosques: this very mosque of mine; the Holy Mosque (in Makkah), and the Aqsa Mosque. ${ }^{\prime 54}$ And instead of presenting himself as the negation of other 
prophets, he presented himself as a synthesis of Abraham and Jesus. Reportedly, the Prophet once said: "I am the (fulfillment of) the prayer of my father Ibrahim, the good-tidings of my brother Isa, and the (realization of) my mother's dream." ${ }^{55}$ In this perspective, the Farthest Mosque is not abandoned; rather, it is subsumed into a higher level of universal monotheism.

Having followed the Prophet's "spiritual" track alluded to above, I now pick up the other one, namely, the political track that sought to forge a broad tribal coalition against the Quraysh. One of the most striking indicator of that policy was, of course, the Sahifat al-Madinah (the Charter of Madinah), the broad-based agreement that brought together several of Madinah's Jewish communities and the Muslim to protect the Madinah against aggression by the Makkan forces. ${ }^{56}$ The Prophet feared these forces because Makkah had become, in addition to its place as a temple-city, an important caravan city. ${ }^{57}$ Its tribal chiefs served as the Ka'bah's custodians and administrators, and also took care of the pilgrims who flocked to it each year.

These chiefs had become both politically and economically powerful figures. Understandably, the Qur'anic criticism and the Prophet's direct attacks targeted this gross material power along its ideological justification and social base. In contrast to the Qurayshi leaders' unmitigated parochial outlook, which was based mainly on noble descent, the Prophet was intent on presenting a more inclusive Islamic nationalism based on belief and capable of aggregating a broader coalition of ethnic groups, social classes, and religious affiliations. The ultimate goal here was to present a viable substitute system. Qur'an 2:143 proclaims this substitute system to be the justly balanced community (ummatan wasatan). ${ }^{58}$

Parallel to that, but linked to it, was the Prophet's intensive effort to link his new ummah to the older Abrahamic religious tradition, the residuals of which were still lingering in the Arabs' hearts. In the absence of a strong central authority, it is reasonable to assume that the Prophet considered the Makkan shrine an important locus around which Arab popular feeling could coalesce. The future of his emerging Muslim community was closely related to how well he could use the ancient Abrahamic religious symbols and sentiments to integrate the dispersed and warring Arab tribes into some kind of supra-tribal unity. ${ }^{59}$

This envisaged integration did not mean endorsing their entire belief system or pseudo-religious practices. On the contrary, the Prophet, backed by the Qur'an, never hesitated to expose the Qurayshi leaders' religious and moral errors, portray them as deniers of the truth (al-mukādhibün), or communicating the most daring Qur'anic ideas about an alternative just society. In order to minimize the expected violent reactions, he was keen to follow a gradual 
reformative method rather than a revolutionary one. In a candid conversation with his wife A'ishah, he once stated that "were it not that your people (i.e., Quraysh) had a recent experience of the jähilīyah (hadithu 'ahdin bi aljāhilìyah), I would have 'demolished' the Ka'bah and 'reconstituted' it on the Abrahamic foundations." 60

To be sure, the concept of "reconstituting it on the Abrahamic foundations" referred to in the Hadith was not confined to the pre-Islam Arab traditions. Rather, it could be extended to some Jewish theology and practices, which certainly aggravated the antagonism between the Prophet and the Jewish communities in the same way as it did with his Arab opponents. Madinah's Jewish leaders were disappointed, among other things, by the changed qiblah. However, they might have been even more annoyed by what they saw as a wholesale process of reappropriating the Abrahamic heritage. After all, Muhammad was preaching that "Abraham was not a Jew, nor yet a Christian" (Q. 3:67), but rather a common ancestor of all monotheists - Muslims included. For one who is not quite aware of what reconstituting a new Islamic monotheism on the "Abrahamic foundations" means, namely, that both Jewish and Arab parochialism are superseded, it would appear as if Muhammad "hated" the Jerusalem qiblah, as Kister ${ }^{61}$ and others have claimed.

\section{Conclusions}

Pulling together the scattered pieces of information on the qiblah, we may venture to summarize the controversy in a few points. Like many other Islamic rituals, prayers were gradually instituted over a number of years. At the very initial stage they were confined to the Dawn and Evening prayers, ${ }^{62}$ as well as to the solitary night prayers accompanied by a prolonged recitation of the Qur'an. At this stage, no public call to prayer (adhān), collective prayers during the day, or qiblah were required. In the second stage, when the number of Muslims increased, they were allowed to pray collectively but only in Dar alArqam or in the city's outer mountainous surroundings ${ }^{63}$ It was probably during this stage that the question of qiblah arose, and it was possible that the Prophet chose to pray toward Jerusalem and Makkah simultaneously. It might have been at the third stage, immediately after the Prophet's Night Journey, that the Jerusalem qiblah was reaffirmed, since the daily canonical prayers were finally prescribed during that night. A year later, the Muslims migrated to Madinah, where they continued to pray toward Jerusalem, as one could no longer pray to Makkah and Jerusalem simultaneously. 
In turning away from the Ka'bah, the Prophet's chief aim was to avoid confrontations with the Quraysh. Perhaps he also wanted to expose his followers to a spiritual sense of hijra and to make them feel the universal, extratribal aspect of Islam. His "return" to the Ka"bah policy was a resumption of the same earlier policy but with some differences: the shift in the balance of power as well as the adoption of a trans-racial, extra-sectarian value system that stood in contrast to those of the Quraysh in Makkah and the Jews.

While we agree that the Prophet had attempted to win over the Jews and was certainly disappointed by their opposition, it is important to realize that the changing the qiblah and linking up Islam with the Abrahamic heritage was not necessarily a reaction to that. Numerous Makkan verses and concrete incidents show that he had been intent upon returning to Makkah and the Ka'bah years before he ever met with any Jews. Moreover, the phenomenon of a political rapprochement ending up in bitter estrangement is hardly unique. The Prophet's reconciliatory attempts toward his own war-like fellow Arabs also sometimes failed and ended in bloody confrontations.

Finally, two methodological points concerning how we analyze and interpret the Qur'anic concepts need to be made. The first concerns the method used in this paper: "separating" the concept of qiblah in order to discern its historical and political dimensions. Although this concept is closely connected with other Islamic elements (e.g., prayers and pilgrimage), its analytical separation has proved to be useful. For instance, it has allowed us to focus on the qiblah's external "political dimensions," unearth its "historical" genealogy, and grasp its cultural connotations. Such a separation in no way entails separating Qur'anic verses or chapters into small, disconnected boxes.

This brings us to the second methodological point, which is related to what we see as the main shortcoming of existing tafsir literature, particularly when dealing with the qiblah verses. Most commentators have limited themselves to analyzing the qiblah change and the few verses related to it. Disconnecting these verses from earlier Makkan revelations has caused great confusion. Had those commentators extended their research into the Makkan period, they might have noticed that the Prophet's awareness of and attachment to Jerusalem neither grew suddenly at Madinah nor was it prompted by Jewish opposition. And if they had been willing to scrutinize the relevant wider Qur'anic context or pay attention to the progressive nature of Qur'anic legislation, they could have stopped looking for non-existent "abrogated" verses.

In his Islam and Modernity, Fazlur Rahman (d. 1988) castigates Muslim commentators and jurists for their "atomistic" approach to the Qur'an and 
speaks out against what he calls "a general failure to understand the underlying unity of the Qur'an," which yields a definite weltanschauung. ${ }^{64}$ In this research, it has become clear to us that the whole controversy over the qiblah issue has been fuelled by this type of "atomistic" approach. Had the commentators not focused exclusively on one verse, they could have seen the wider theme of universal monotheism that the Qur' an had been driving at since the earlier revelations of the Makkan chapters. And had not some of the modern scholars of Islam shared this same approach, they could have seen that the Prophet's return to Makkah was not occasioned by an anti-Jewish Islamic stance or a pro-Arab sentiment, but rather as part of an earlier, wider plan of "withdrawal and return" that he had set his mind to since the Divine promise had been conveyed to him in Q. 14 and Q. 17.

Finally, it should be recalled that the qiblah, as a mere geographical expression, has no significance. It becomes important only as a spiritual symbol that refers to the core value of tawhi $d$ (unification) that represents the "defining characteristics" of the Islamic monotheistic belief system, as well as to the universal community of Islam. "In any culture," says Karl W. Deutsch, "certain behavior patterns stand out as a leading or model patterns; certain groups of persons as cultural models and bearers of prestige; certain regions as cultural centers." ${ }^{\prime 65}$ Our addition of "certain spiritual symbols" would be quite in line with this statement.

\section{Endnotes}

1. For a concise summary of Ibn Abbas' efforts in tafsir , as well as his disciples and the reliability of their reports, see Muhammed Husain al-Dhahabi, Al-Tafsìr wa al-Mufassirūn (Cairo: Maktabat Wahba, 2000), 1:50-62. And see also Muhammad al-Fadil ibn 'Ashur, Al-Tafsīr wa Rijāluh (Cairo: Dar al-Salam, 2008), 26-31; and I. Goldziher, Madhāhib al-Tafsìr al-Islāmī, tr. Abd al-Halim al-Najjar (Cairo: Maktabat al-Khanji, 1955), 82-99.

2. See al-Tabari, Jāmi ' al-Bayān, ed. Sidqi Jamil al-Attar (Beirut: Dar al-Fikr, 1988), 2:7-8; al-Zamakhshari, Al-Kashshäf, ed. 'Adil Ahmed Abd al-Mawjud (Riyadh: Maktabat al-'Ibaykan, 1998), 1:340-43; and al-Qurtubi, Abdullahi Muhammad ibn Ahmed al-Ansari (d. 671), Ahkām al-Qur'ān, ed. Arfan al'Asha (Beirut: Dar al-Fikr, 1993), 1:140; and Ibn Kathir (d. 774), Tafsìr alQur'ān al- 'Aż̄im (Beirut: Dar al-Kutub al-'Ilmiyyah, 1998), 1:324-32.

3. Mu'awiyyah ibn Abi Salih himself was reporting on the authority of Ali ibn Abi Talha al-Hashimi. The latter was a reliable transmitter, says Ahmed M. Shakir, but he has been criticized either because of his Shi'ah leanings or because he did not hear directly from Ibn Abbas. However, the meaning of the hadith, says Ahmed M. Shaker, is sound and was related to Ibn Abbas through other ways. 
See Ahmed M. Shaker's commentary note in al-Tabari, Jāmi ‘ al-Bayān, ed. Mahmud Muhammad Shakir (Cairo: Maktabat Ibn Taimiyyah, n.d.), 2:527.

4. Ibid., 2:8.

5. See the text of this account in ibid., 2:6.

6. Sa'id Ibn al-Musayyib, a distinguished second-generation scholar, says that the Ansar had been praying toward Jerusalem three years before the Prophet's arrival. See al-Tabari, Jāmi ‘ al-Bayān, 2:7.

7. See al-Zamakhshari, Al-Kashshäf, 1:340. Sticking to this opinion consistently, al-Zamakhshari contends that even Moses and his Israelite followers were instructed, during their stay in Egypt, to pray toward Makkah. See his comments on Q. 10:87 in ibid., 3:166.

8. Ibn Jurayj (d. 150/761), Tafsīr Ibn Jurayj, ed. Ali Hasan Abd al-Ghani (Cairo: Maktabat al-Turath al-Islami, 1992), 41. His full name is Abd al-Malik ibn Abd al-Aziz ibn Jurayj. His grandfather Jurayj was a Roman slave. Reportedly, Ibn Jurayj was the first one to compile the Hadith. See K. Brockleman, trans. Mahmud Fahmi Hijazi, Tārīkh al-Adab al-Arabī (Cairo: al-Haiyaa al-Misriyyah al'Ammah li al-Kitab, n.d.), 3:161.

9. His full name is Abd al-Rahman ibn Aslam al-Madani.

10. Ibn Zayd's opinion found its way into the abrogation thesis. See, for instance, Abu Ja'far al-Nahhas, Al-Nāsikh wa al-Mansūkh, ed. Muhammed Abd al-Salam Muhammad (Kuwait: Maktabat al-Falah, 1988), 76.

11. See Ahmed ibn Hanbal, Al-Musnad (1/325) and al-Zamakhshari, Al-Kashshāf, $1: 340$.

12. Al-Tabari introduced these two positions as follows: "Scholars have differed on that; some of them said that (the decision) was a choice made by the Prophet; others said that it was based on a divine command." He states that the first position was represented by 'Ikrimah, al-Hasan al-Basri, and Abu al-'Aliyah. The second position was related to Ibn Abbas through Ali ibn Abi Talha. See alTabari, Jāmi ‘ al-Bayān (Beirut: Dar al-Fikr, 1988), 2:7-8.

13. Ibid., $2: 7$

14. Al-Qurtubi is one of the mufassirün who concedes that there was no Qur'anic verse to be abrogated, and hence it was the Sunnah that was abrogated. According to him, this in itself was evidence that the Qur'an could abrogate the Sunnah. Al-Qurtubi, Ahkām al-Qur'ān, 1:140.

15. This is al-Razi's position (d. 604). See al-Razi, Al-Tafsīr al-Kabīr (Beirut: Dar al-Kutub al-'Ilmiyyah, 2000), 2:102.

16. On the meaning of inqița ' (disconnection), see Abd Abdullah al-Nisaburi, Kitāb Ma 'rifat 'Ulüm al-Hadìth (Beirut: Dar al-Afaq al-Jadidah, 1980), 27. Some scholars, however, argued that the disconnectedness of Ibn abi Talha's report is insignificant because he had also heard it from Mujahid, and both of them are reliable reporters.

17. For the definition of hadīth mawqūf, see al-Hakim al-Nisaburi, Kitāb Ma 'rifat, 20. See also Ibn al-Salah, Muqaddimat Ibn al-Salāh, ed. Salah ibn Muhammed ibn 'Iwaydha (Beirut: Dar al-Kutub al-'Ilmiyyah, 2010), 73. 
18. This account, which is reported on the authority of Sa'id ibn al-Musayyib through Qatadah, affirms that the Ansar had been praying toward Jerusalem three years before the Prophet's arrival. See al-Tabari, Jāmi ' al-Bayān, 2:7.

19. According to Ibn Hajar, al-Bukhari alluded to this acceptable opinion, and alHakim and others validate the hadith on which it is based. See Ibn Hajar al'Asqalani, Fath al-Bārī bi Sharh Ṣahīh al-Bukhārī (Beirut: Dar al-Fikr, 1996), $1: 133$.

20. Al-Suhaili, Abdul Rahman (d. 581), one of the main commentators on the Sirrat Ibn Hishām, agrees with the united Makkah-Jerusalem qiblah and contends that there have been conflicting reports on this issue because it was not clear to the people whether the Prophet was indeed praying toward the two qiblahs simultaneously. They realized that only after he left Makkah. See his Al-Rawdh alUnuffi Sharh al-Sìrah al-Nabawīyah li Ibn Hishām, ed. Abdul Rahman al-Wakil (Cairo: Dar al-Kutub al-Hadithah, 1969), 4:114. As far as I know, probably only Ibn Kathir (d. 774) noticed this. "When the Prophet migrated to Madinah," he says, "it became impossible for him to combine the two [qiblahs]." Ibn Kathir, Tafsìr al-Qur'ān al- 'Aż̄m (Beirut: Dar al-Kutub al-'Ilmiyyah, 1998), 1:325.

21. See, for instance, William H. McNeill, The Rise of the West: A History of Human Community (Chicago: University of Chicago Press, 1991), 421. See also Albert Hourani, A History of the Arab Peoples (London: Faber \& Faber, 1991), 18.

22. A. J. Wensinck, "The Kibla," in The Encyclopedia of Islam, vol. v, new edition. ed. C. E. Bosworth et al. (Leiden: E. J. Brill, 1986), 82.

23. W. Montgomery Watt, Muhammad: Prophet and Statesman (Oxford: Oxford University Press, 1961), 144.

24. Quoted in al-Qurtubi, see al-Qurtubi, Ahkām al-Qur'ān, 1:140.

25. Sayyid Qutb, Fī Zilāl al-Qur'ān (Cairo: Dar al-Shuruq, 1998), 1:127. He contends that the new Arab converts were turned away from the Ka'bah so as to purify them from the residual effects of the pre-Islam era.

26. Al-Bukhari, Muhammad ibn Isma'il, Șaḥ̄ḥ al-Bukhārī (Beirut: Dar al-Fikr, 1998), 15:176-78. See also al-Asqalani, Ibn Hajar, Fath al-Bārī, 2:60.

27. Al-Asqalani, Ibn Hajar, Fath al-Bārī, 1:132. As for Ibn Hajar's personal opinion, he clearly supports the Makkan-Jerusalem united direction because, in his view, it combines the two possible answers and because al-Hakim and other Hadith experts have validated the report on the authority of Ibn Abbas.

28. Muslim ibn al-Hajjaj, Sahīh Muslim, ed. al-Nawawi, 9:114-37. See hadith nos. 1333, 1352, 1397.

29. Ibn Hisham, Al-Sīrah al-Nabawīyah, ed. Mustafa al-Saqqa (Beirut: Dar Ihya' al-Turath al-'Arabi, 1997), 1:351. See also Ibn al-Jaziri, 'Izz al-Din Ibn al-Athir (d. 1234), Usd al-Ghābah fì Ma 'rifah Șahābah (Beirut: Dar al-Fikr 1998), 3:28081. Ahmad ibn Hanbal reports a similar account in his Musnad.

30. Ibn Hisham, Al-Sìrah al-Nabawīyah, 1:300.

31. Ibn 'Abd al-Barr (d. 463), Al-Durār fì Ikhtisār al-Maghāzī wa al-Siyār, ed. Shawqi Daif (Cairo: Dar al-Ma‘arif, 1991), 48. 
32. This is the number given by Ibn Ishaq. See Ibn Hisham, Al-Sìrah al-Nabawīyah, $1: 368$.

33. For a thorough discussion of the role of the Prophet's grandfathers Hisham and Abd al-Muttalib in establishing Makkah's institutions and traditions, see Husain Mu'nis, Tārīkh Quraysh (Beirut: Dar al-Manahil, 2002), 115, 139.

34. Ibn Hisham, Al-Sirah al-Nabawīyah, 2:52-53.

35. See al-Mas'udi, Ali ibn al-Hasan (d. 345), Murūj al-Dhahab wa Ma'ādin alJawāhir, ed. Sa'id Muhammed al-Laham (Beirut: Dar al-Fikr, 1997), 2:275.

36. See al-Zamakhshari, Al-Kashshäf, 4:239.

37. See, for instance, Q. 22:52: "Never did We send a messenger or a prophet before thee, but, when he framed a desire, Satan threw some (vanity) into his desire: but Allah will cancel anything (vain) that Satan throws in, and Allah will confirm (and establish) his signs."

38. Al-Zamakhshari, Al-Kashshāf, 1:340.

39. Compare, for instance, the following Makkan verses: "And the places of worship are for Allah alone " (Q. on your heels in arrogance: talking nonsense about the (Qur'an) like one telling fables by night" (Q. 23:66-67); "Let them worship the Lord of this House, Who provides them with food against hunger, and with security against fear" (Q. 106:3-4); "They say: 'If we were to follow the guidance with thee, we should be snatched away from our land.' Have we not established for them a secure Sanctuary, to which are brought as tribute fruits of all kinds a provision from ourselves but most of them understand not" (Q. 28: 57) with the verses " and who is more unjust than he who forbids that in places of worship of Allah, His name should be celebrated" (Q. 2:114); "Be sure We shall test you with something of fear and hunger, some loss in goods, lives and the fruits of your toil, but give good tidings to those who patiently persevere" (Q. 2:155); "It is not righteousness that ye turn your faces towards East or West; but it is righteous to believe in Allah..." (Q. 2:177); "And remember Abraham said: my Lord, make this a City of Peace, and feed its people with fruits - such of them as believe in Allah and the Last Day" (Q. 2:126), respectively. The comparison shows clearly how the same ideas about the qiblah, which were concisely expressed in the Makkan revelations, were expanded and elaborated in the Madinan revelations.

40. Like, for instance, the universality of Muhammad's message (referred to in this verse as al-nās [humanity]), whereas the missions of other prophets were "to bring out qawmaka (thy people)."

41. The Holy Qur'an, trans. Abdullah Yusuf Ali (Madinah: The Presidency of Islamic Researches, 1413), 703.

42. There is an intense debate among both Muslim and western scholars on how Abraham managed to visit Makkah. For a detailed analysis of the Islamic sources, see Reuven Firestone, “Abraham's Journey to Makkah in Islamic Exegesis: A Form-Critical Study of a Tradition,” Studia Islamica 76 (1992): 5-24.

43. On some occasions, such as Q. 28:5, the Qur'an refers explicitly to "those who were depressed in the land." 
44. For the Qur'anic promise that believers will ultimately triumph, see Q. 30:47, 30:60, and 7:129.

45. Plato, Plato's Republic, tr. G. M. A. Grube (Indianapolis: Hackett, 1974), 168.

46. In his Muqaddimah, Ibn Khaldun did not explicitly mention the idea of "withdrawal and return." However, he did stress history's "cyclical" nature and the unceasing opposition between nomads and sedentary populations. He must have drawn both concepts, among other things, from Qur'anic sources, as attested to by his reflections on Q. 6:26, where he contended that the Israelites were intentionally left to "wander through the wilderness for forty years" because during their Egyptian bondage they had lost all of the necessary characteristics needed by a group to triumph over their enemies. Returning triumphantly to the promised land required the rebirth of a new younger generation, which takes years of labor and suffering. See Ibn Khaldun, Maqaddimat Ibn Khaldūn (Beirut: Dar al-Kutub al-'Ilmiyyah, 2009), 112.

47. See Arnold J. Toynbee, A Study of History: Abridgement of Volumes i-vi by D. C. Somervell (Oxford: Oxford University Press, 1946), 228. According to one scholar, Toynbee was not just influenced by Ibn Khaldun; he had, in fact, "appropriated him as intellectual ancestor." See Robert Irwin, "Toynbee and Ibn Khadun," Middle East Studies 33, no. 3 (July 1997): 468.

48. In Fazlur Rahman's view, the whole idea behind the Prophet's hijra and what happened therein are intelligible only in the light of his over-riding concern to take Makkah. See Fazlur Rahman, "Pre-Foundations of the Muslim Community in Makkah," Studia Islamica 43 (1976): 21.

49. John Dewy, Reconstruction in Philosophy (New York: The New American Library, 1952), 29.

50. Muhammad Asad, The Message of the Qur'an, Translated and Explained (Gibraltar: Dar al-Andalus, 1980), 998.

51. This was not the only time when the Prophet reportedly waited for permission. On the day of his hijra, he confided to Abu Bakr that he had been "granted permission” to leave Makkah. See Ibn Qayyim al-Jawziyyah (d. 751), Zād al-Mi ‘ $\bar{a} d$ fì Hadīy Khayr al-'Ibād, ed. Mustafa Abd al-Qadir 'Ata (Beirut: Dar al-Kutub al-'Ilmiyyah, 2007), 322.

52. Al-Bukhari reports on the authority of Jabir that the Prophet used to pray on his (moving) camel in whatever direction it went, but that he would stop and face the qiblah if he wanted to perform one of the canonical prayers. See al-Asqalani, Ibn Hajar, Fath al-Bārī, 2:62.

53. Ibn Majah, Abdullahi Muhammad ibn Yazid al-Quzwini (d. 275), Sunan Ibn Mājah, ed. Sidqi Jamil al-Attara (Beirut: Dar al-Fikr, 1995), 1:244.

54. Al-Bukhari and Muslim report this hadith. See al-Asqalani, Fath al-Bārī, 3:383 and see also Ibn al-Hajjaj, Șahịh Muslim, 9:142.

55. Al-Tabari, Jāmi ‘ al-Bayān, 1:773. See also Al-Zamakhshari, Al-Kashshāf, 1:323.

56. For the text of this document, see Ibn Hisham, Al-Sìrah al-Nabawìyah, 2:11516. 
57. For pre-Islamic Makkah's economic importance and the trade activities of Quraysh and its allies, see Mahmoud Ibrahim, "Social and Economic Conditions in Pre-Islamic Makkah," International Journal of Middle East Studies 14, no. 3 (1982): 347-50.

58. This is how Abdallah Yusuf Ali translated the term ummah wasat. Muhammad Asad translated it as the "community of the middle way" and the "middlemost community." See Muhammad Asad, The Message of the Qur'an, 30.

59. T. Izutsu, Ethico-Religious Concepts in the Qur'an (Montreal: McGill University Press, 1966), 61.

60. Muslim, Abu al-Husain ibn al-Hajjaj (d. 261), Șahīh Muslim, ed. Al-Imam alNawawi (Beirut: Dar al-Kutub al-'Ilmiyyah, 1995), 9:75. In this version, jāhilīyah is replaced by kufr.

61. As quoted in Suliman Bashear, "Qur'an 2:114 and Jerusalem," Bulletin of the School of Oriental and African Studies, University of London 52, no. 2 (1989): 230. A detailed account of the political and military struggles between Muhammad and Madinah's Jewish leaders can be found in Muhammad Husain Haykal, Hayāt Muhammad (Cairo: Dar al-Ma'rifah, 2000), 229-31.

62. See Ibn al-Jazri, Usd al-Ghābah, 1:30. See also Ibn Hajar al-Asqalani, Fath alBārī, 2:5-6, 9-11.

63. Ibn al-Jazri, Usd al-Ghābah, 1:30.

64. Fazlur Rahman, Islam and Modernity (Chicago: The University of Chicago, 1982), 2-3. Some scholars and commentators had noticed this kind of "underlying unity" of the Qur'an and referred to it as 'ilm al-munāsabah. See, for instance, al-Zarkashi, Badr al-Din Abu Abdallah (d. 794), Al-Burhān fì 'Ulüm al-Qur'ān, ed. Mustafa Abdulgadir 'Atta (Beirut: Dar al-Kutub al-'Ilmiyyah, 2007), 1:42; and Muhammed Abdullahi Darraz, Al-Naba al-Adhim (Doha-Qatar: 2007), 143, particularly his intensive analysis of Q. 2:148-94.

65. Karl W. Deutsch, Nationalism and Social Communication (Cambridge, MA: The M. I. T. Press, 1962), 38. 